\title{
RAPD MARKERS AND BLACK PINE (PINUS NIGRA ARNOLD) INTRASPECIES TAXONOMY - EVIDENCE FROM THE STUDY OF NINE POPULATIONS
}

\author{
Zlatko LiBer ${ }^{1}$, Toni Nikolić1 ${ }^{\text {, BožEnA Mitić }}{ }^{\text {, Zlatko ŠAtović }}{ }^{2}$ \\ ${ }^{1}$ Department of Botany, Faculty of Science, University of Zagreb \\ Marulićev trg 20/2, HR-10000 Zagreb, Croatia \\ ${ }^{2}$ Department of Seed Science and Technology \\ Faculty of Agriculture, University of Zagreb \\ Svetošimunska 25, HR-10000 Zagreb, Croatia \\ e-mail: zlatko.liber@botanic.hr
}

(Received: December 20, 2002. Accepted: May 23, 2003)

\begin{abstract}
Although intraspecies researches within the black pine (Pinus nigra Arnold) have a long tradition, the intraspecies taxonomy, classification and chorology are still unclear. Among the numerous reasons that have caused this situation the most important are: the absence of a study that would completely cover the whole range of this species, the impossibility of connection of results of the existing detailed studies of certain areas, and the high variability of traits which have been used so far. Since the characteristics of the molecular systematic techniques could make possible the research free of the mentioned shortages, the intention of this study was to determine the relationships among nine populations of black pine using the random amplified polymorphic DNA (RAPD). The obtained results were compared to the recent results of the morphological and anatomical analysis of the leaves of the same populations. The RAPD results clearly divided the Croatian populations from populations of Austria (subsp. nigra) and Turkey (subsp. pallasiana), while among Croatian populations, as in previous study, the existence of several groups (subsp. illyrica, subsp. dalmatica and transitional population between them) was noticed. It is assumed that the optimisations conducted in this study will finally make possible estimating the relationships on the level of the whole range of the black pine and the classification based on molecular traits that are probably less dependent on environmental influences than it has been the case with the characteristics mostly used so far.
\end{abstract}

KEY WORDS: black pine, distribution, intraspecies taxonomy and classification, RAPD.

\section{INTRODUCTION}

The distribution of black pine (Pinus nigra Arnold) is tied to the Mediterranean Basin. In accordance with the geographic and topographic diversity of this region the black pine has a discontinuous range (Fig. 1), and it is an extremely variable species (Fukarek 1958; Vidaković 1991; Gaussen et al. 1993).

Although the intraspecies researches within the black pine have a long tradition (e.g. Ronninger 1924; Georgescu 1937; Schwartz 1938; Delevoy 1949; Fukarek 1958; Gaussen et al. 1964, 1993; Ivanov 1971; Arbez et al. 1974; Nikolić and Tucić 1983; Vidaković 1991; Scaltsoyiannes et al. 1994; Raffii et al. 1996; Aguinagalde et al. 1997), intraspecies taxonomy, classification and chorology are still unclear (Fukarek 1958; Vidaković 1991; Gaussen 1993; Barbéro et al. 1998). Among the numerous possible reasons for having the mentioned problems the most important are: the absence of a research which would cover the whole range of this species (Vidaković 1991, Barbéro et al.
1998), integrating of the present detailed studies of certain areas is not possible because of the differences in samples and methods (e.g. Hamrich et al. 1979), the black pine is extremely variable in morphological and anatomical features that have been used in intraspecies taxonomy, classification and chorology so far (e.g. Vidaković 1991; Gaussen et al. 1993).

The mentioned problems are especially emphasized in the eastern part of the range of the black pine, which is the biggest but the least studied (Fig. 1). Although the territory of Croatia as a region of the eastern range of the black pine is characterized with a relatively great number of classifications (e.g. Schwartz 1938; Vidaković 1953, 1955, 1957, 1960, 1991; Fukarek 1958; Gaussen et al. 1964, 1993; Domac 1965; Trinajstić 1986; Rauš et al. 1992; Price et al. 1998) only two taxonomic researches have been done up to now (Vidaković 1953; Liber et al. 2002). Although, according to the mentioned classifications, on the territory of Croatia we can distinguish two ( $P$. nigra Arnold subsp. $n i$ gra and $P$. nigra Arnold subsp. dalmatica (Vis.) Franco 


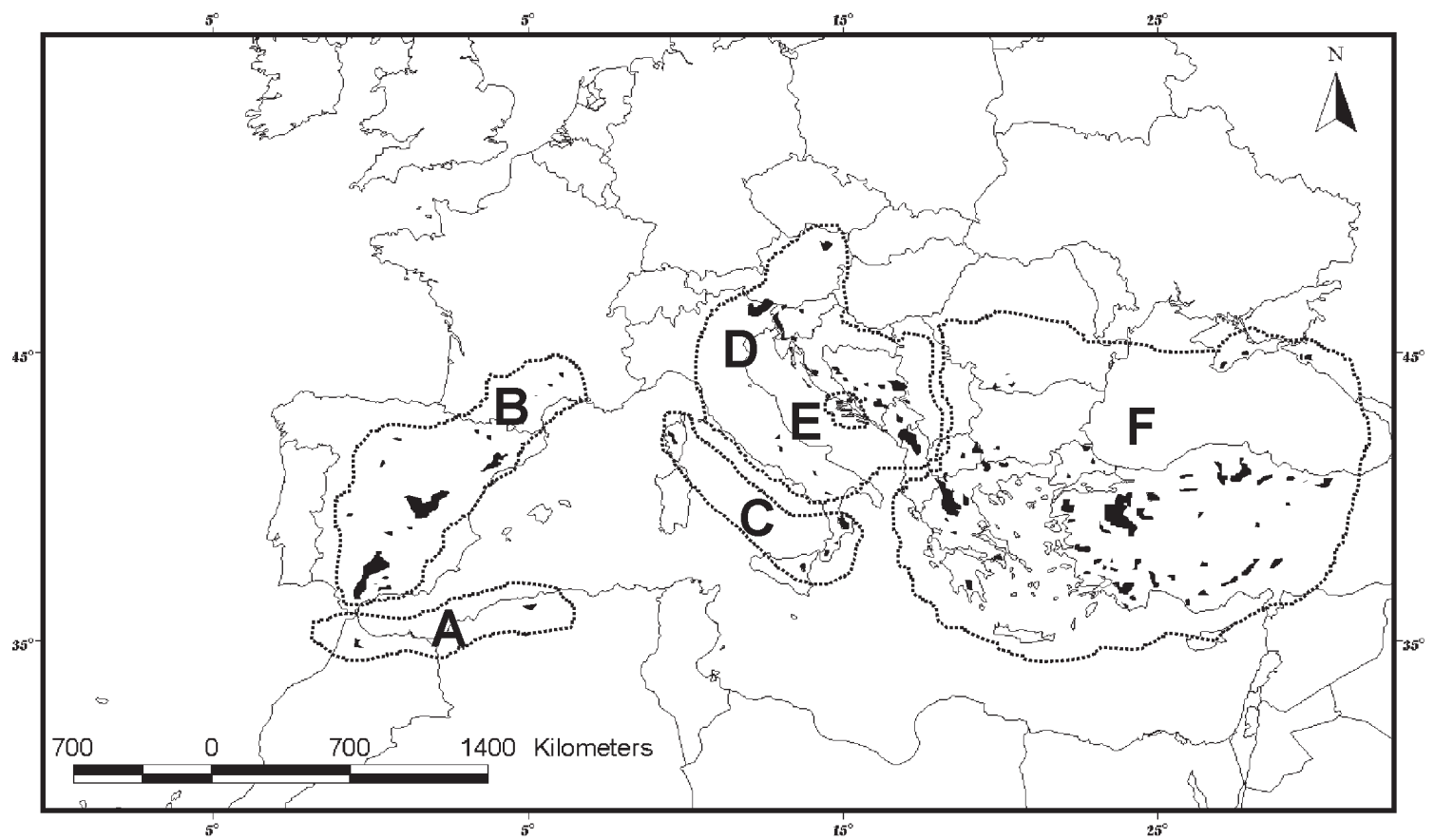

Fig. 1. Discontinuous range and distributions of six subspecies (mostly used classification today) of European black pine (A - Pinus nigra Arnold subsp. mauretanica (Maire \& Peyerimh) Heywood, B - P. nigra Arnold subsp. salzmannii (Dunal) Franco, C - P. nigra Arnold subsp. laricio (Poiret) Maire, D P. nigra Arnold subsp. nigra, E - P. nigra Arnold subsp. dalmatica (Vis.) Franco, F - P. nigra Arnold subsp. pallasiana (Lamb.) Holmboe); E - black pine populations.

/endemic for Croatia/) (Fig. 1 and 2a) or even three subspecies ( $P$. nigra subsp. nigra, $P$. nigra subsp. dalmatica and Pinus nigra subsp. illyrica (Vid.) Fukarek) (Fig. 2b and 2c) and several varieties (Vidaković 1991; Gaussen et al. 1993), the situation in the field is not nearly that simple and the taxonomic status, as well as distribution, of certain taxa have not been clearly defined yet (Liber et al. 2002).

In the last ten years numerous molecular techniques that enabled systematic researches have been applied (Hillis et al. 1996; Soltis et al. 1998), especially after the polymerase chain reaction (PCR) was developed (Mullis et al. 1986; Wolfe and Liston 1998). Many of these techniques have been applied to various taxa of genus Pinus (Price et al. 1998), but none for the intraspecies taxonomy, classification and chorology of the black pine. Since the characteristics of the molecular techniques could enable the research free of shortages of the previous researches (Moritz and
Hillis 1996), the purpose of this research was to determine the relationships among nine populations of the black pine using RAPD-PCR technique (Welsh and McClelland 1990; Williams et al. 1990). Since a similar sample of populations was taken for the previous taxonomic research based on the morphological and anatomical traits (Liber et al. 2002), the choice of populations in this research seemed to be suitable for the first evidence about the usefulness of RAPD for solving taxonomic, classificatory and chorological vagueness within black pine.

\section{MATERIALS AND METHODS}

\section{Plant material}

Seven natural populations of black pine from Croatia, one natural population from Austria and one natural popu-
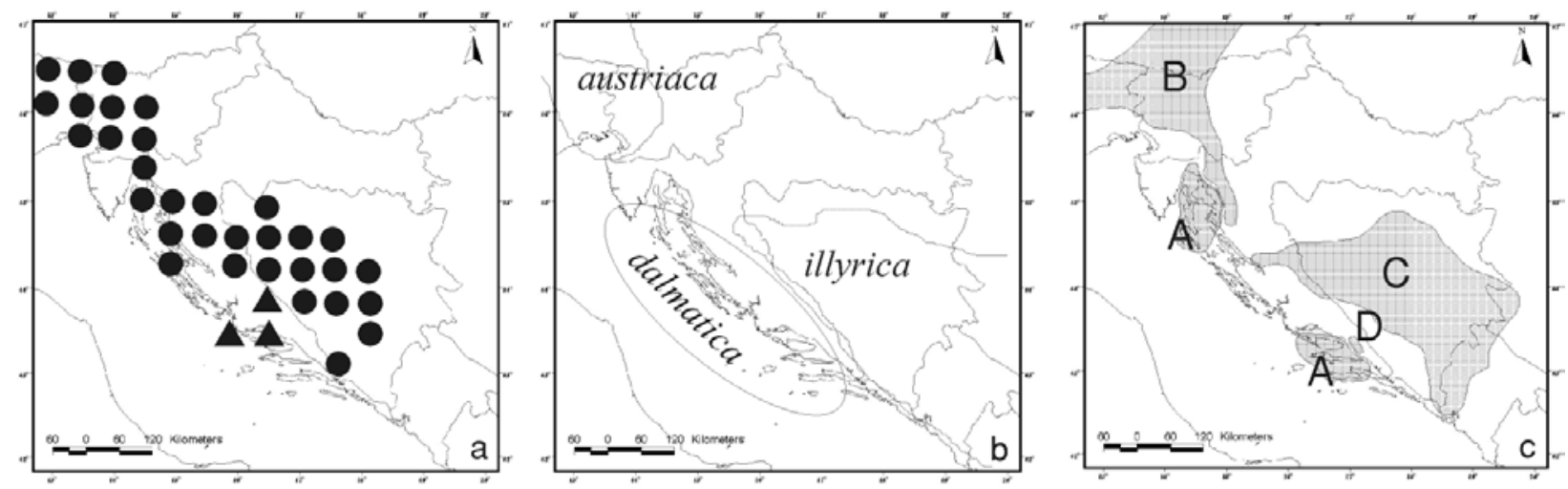

Fig. 2. Distribution of different black pine taxa in Croatia a) adapted from Jalas and Suominen 1988, - Pinus nigra Arnold subsp. nigra, $\boldsymbol{\Delta}$ - Pinus nigra Arnold subsp. dalmatica (Vis.) Franco; b) adapted from Fukarek 1958; c) adapted from Liber et al. 2002, A - Pinus nigra subsp. dalmatica; B - Pinus nigra subsp. nigra, c) - Pinus nigra subsp. illyrica, D - transitional population among A, B, and C. 


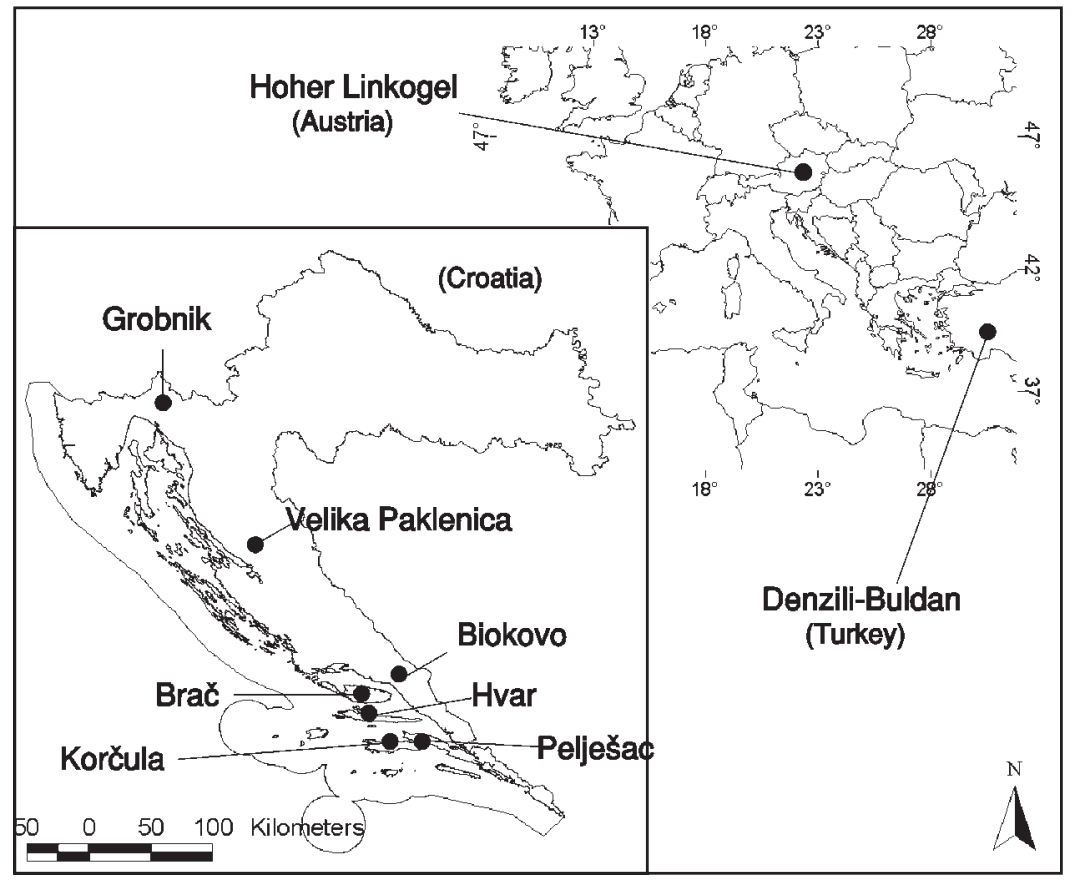

Fig. 3. Geographical position of the analysed black pine populations. lation from Turkey were examined (Fig. 3). Every population was represented by ten individuals. Every individual was represented in RAPD analysis by one megagametophyte. Individuals within each population were chosen so as to try to cover transversely the whole population. All studied plants were determinated according to their taxonomic status in the previous study (Liber et al. 2002) or if they were not included in it, as was the case with the population from Turkey and with the population from the Croatian island of Korčula, they were determinated according to Vidaković's key to identification of black pine subspecies and varieties (Vidaković 1991) (Table 1).

\section{DNA isolation}

Total genomic DNA was isolated from a single megagametophyte per individual tree. The wings were removed from the seeds and after the seeds were thoroughly washed with laundry detergent, tap and distilled water, they were germinated in $1 \%$ hydrogen peroxide for 5 days. After germination the megagametophyte (approximately 30-40 mg) was placed to the $1.5 \mathrm{ml}$ test tube. Total genomic DNA isolation was carried out using the CTAB DNA isolation procedure (Doyle and Doyle 1990) with some modifications. The $200 \mu$ of $4 \times \mathrm{CTAB}$ buffer was added to the test tube with megagametophyte. The megagametophyte was crushed with the help of an appropriate polypropylene pellet pestle. The crushed tissue was thoroughly stirred and incubated for 30 minutes at $55^{\circ} \mathrm{C}$. The extractions were carried out with phenol:chloroform:isoamyl alcohol (25:24:1), and after that twice with chloroform:isoamyl alcohol (24:1). After the last of three 10-minute centrifugations at 12000 $\mathrm{g}$, nucleic acids were precipitated from the top aqueous phase with the addition of 2.5 volumes of the cold absolute ethanol and pelleted by centrifugation (12 $000 \mathrm{~g}$ for $2 \mathrm{~min}$ ). The precipitated nucleic acids were washed out at room temperature keeping over night in wash buffer $(76 \%(\mathrm{v} / \mathrm{v})$ ethanol, $10 \mathrm{mM}$ ammonium acetate). After centrifugation (12 $000 \mathrm{~g} ; 2 \mathrm{~min})$ the supernatant was carefully discarded while washed nucleic acids pellet was dried by keeping at room temperature for about 30 minutes. The nucleic acids were resuspended in $25 \mu \mathrm{l}$ sterilized deionised water which contained $10 \mu \mathrm{g} / \mathrm{ml}$ RNase A. RNA molecules were eliminated by keeping at room temperature for 1 hour at least. The quality and concentration of the total cellular DNAs were established by electrophoresis in $0.8 \%$ agarose by comparison with $\lambda_{\text {DNA }}$ as a standard (Sambrook et al. 1989). DNA samples of particular individual were diluted to the concentration of $50 \mathrm{ng} / \mu \mathrm{l}$. Ten microlitres of total

TABLE 1. Nine black pine populations used in this RAPD study and their possible taxonomic status according to this study and according to morphology and anatomy of leaves.

\begin{tabular}{|c|c|c|c|}
\hline No & Population & Possible taxon according to morphology and anatomy & Possible taxon according RAPD \\
\hline 1. & Höcher Lindkogel (Austria) & P. nigra subsp. nigra ${ }^{1}$ & P. nigra subsp. nigra \\
\hline 2. & Denzili-Buldan (Turkey) & P. nigra subsp. pallasiana ${ }^{2}$ & P. nigra subsp. pallasiana \\
\hline 3. & V. Paklenica (Croatia) & P. nigra subsp. illyrica ${ }^{1}$ & P. nigra subsp. illyrica \\
\hline 4. & Brač (Croatia) & P. nigra subsp. dalmatica ${ }^{1}$ & P. nigra subsp. dalmatica \\
\hline 5. & Hvar (Croatia) & P. nigra subsp. dalmatica ${ }^{1}$ & P. nigra subsp. dalmatica \\
\hline 6. & Korčula (Croatia) & P. nigra subsp. dalmatica ${ }^{2}$ & P. nigra subsp. dalmatica \\
\hline 7. & Pelješac (Croatia) & P. nigra subsp. dalmatica ${ }^{1}$ & transitional form between subsp. dalmatica and illyrica \\
\hline 8. & Grobnik (Croatia) & P. nigra subsp. dalmatica ${ }^{1}$ & P. nigra subsp. illyrica \\
\hline 9. & Biokovo (Croatia) & transitional form among subsp. nigra, dalmatica and illyrica ${ }^{1}$ & P. nigra subsp. illyrica \\
\hline
\end{tabular}

1 according to Liber et al. 2002, ${ }^{2}$ according to the key to identification of black pine subspecies and varieties (Vidaković 1991) 
DNA samples of every individual were mixed together into the appropriate population DNA pool (Furman et al. 1997). This population DNA pool, in which DNA concentration was $50 \mathrm{ng} / \mathrm{\mu l}$ (the DNA concentration of each individual was $5 \mathrm{ng} / \mu \mathrm{l})$, represented the starting material for the RAPD amplification.

\section{DNA amplification}

In total of 34 RAPD primers (Operon Technologies) were used, 20 primers from kit B and primers OPA-06, -08, 09, -12; OPE-08, -09, -12, -17; OPG-09, -10, -12; OPJ-01, -08 and OPX-04. The amplification was carried out in total volume of $25 \mu \mathrm{l}$ which contained $50 \mathrm{ng}$ of pooled DNA of a particular population, 5 pmol of RAPD primer, 100 $\mu \mathrm{M}$ of each of the four dNTPs, $1 \times$ PCR buffer, $2.5 \mathrm{mM}$ $\mathrm{MgCl}_{2}$ and 0.8 unit of AmpliTaq DNA polymerase (Perkin Elmer). One RAPD amplification with a defined primer included 10 samples ( 9 populations of black pine and one control sample without DNA). RAPD amplifications were carried out in 40 cycles of the following parameters: $1 \mathrm{mi}$ nute at $94^{\circ} \mathrm{C}, 1$ minute at $36^{\circ} \mathrm{C}$ and 2 minutes at $72^{\circ} \mathrm{C}$. At the end the final cycle, which lasted 10 minutes at $72^{\circ} \mathrm{C}$, was carried out. All amplifications were done at Mastercycler Personal Thermal Cycler (Eppendorf-Netheler-Hinz $\mathrm{GmbH})$. The amplified DNA fragments after horizontal electrophoresis in $1.4 \%$ agarose were visualized by ethidium bromide staining. The molecular weights of the RAPD fragments were determined with the 100 bp PCR standard (Bio-Rad).

\section{Data analysis}

In order to determine the relations among populations, the obtaind RAPD results were analyzed using similarity measures (Harris 1998) and multivariate statistics (Demeke and Adams 1994). The RAPD fragments with the same molecular weight and mobility were treated as identical fragments. In the data matrices, the presence of a RAPD fragment was coded as 1 , whereas the absence of the fragment was coded as 0 . Because of the unknown reason why RAPD products are absent pairwise genetic distances were calculated using Nei and Li (Method 1 in TREECON program; Nei and Li 1979) and Jaccard's coefficient (Method 2 in TREECON program; Link et al., 1995), which measure the proportion of shared product presences. Cluster analysis of these distances was conducted with neighbor joining (NJ) (Saitou and Nei 1987) and unweighted pair-group method with arithmetic means (UPGMA; Sneath and Sokal 1973) using TREECON program (Van de Peer and De Wachter, 1994). Statistical support of the branches was tested with a bootstrap analysis (Felsenstein, 1985) with 1000 data resamples. Multivariate relationships among populations were revealed through a principal coordinate analysis (PCO) using NTSYSpc software Version 2.10 (http://www.ExeterSoftware.com).

\section{RESULTS}

In this research the so-called population DNA pooling strategy was applied (Furman et al. 1997). Because in this strategy the competition between products (between sites within a genome, between genomes and between genotypes) can lead to errors in genetic relatedness using RAPD

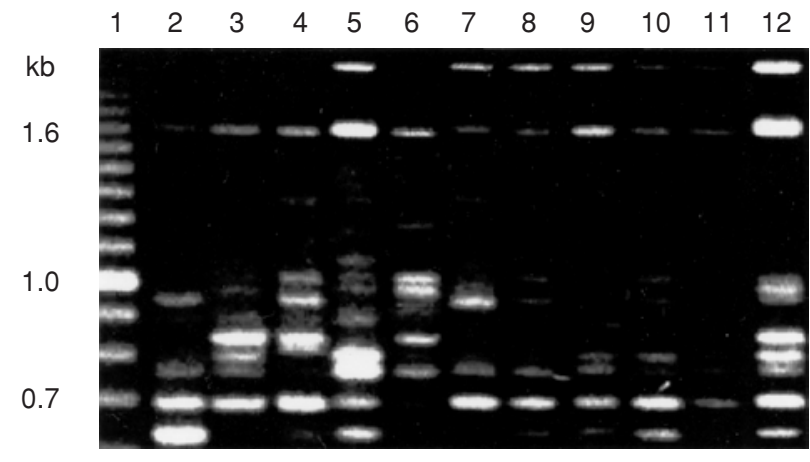

Fig. 4. Accumulation of RAPD bands of ten individuals (primer OPB-18) in pooled DNA of population. Lane: $1.100 \mathrm{bp}$ PCR standard (Bio-Rad), 2 - 11. RAPD profile of DNAs of ten individuals from the island of Hvar, 12. RAPD profile of the pooled DNA that represent population from the island of Hvar.

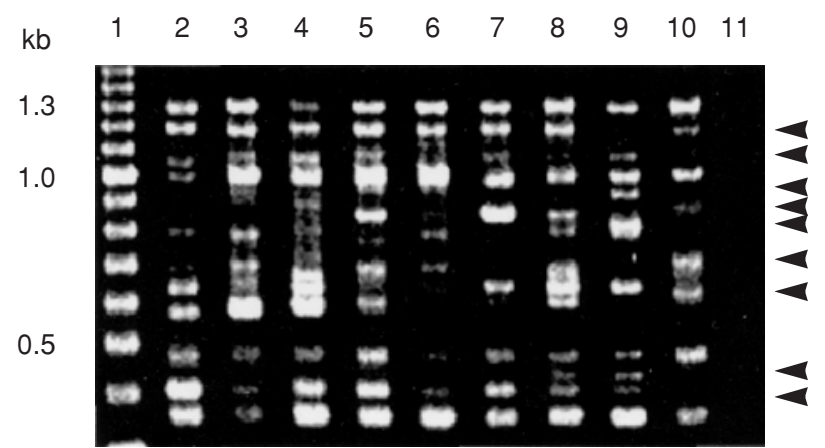

Fig. 5. Pooled DNAs of nine populations of black pine amplified by OPB-08 primer (5'-GTCCACACGG). Lane 1. 100 bp PCR standard (Bio-Rad); Lanes 2-10 populations: 2. Brač, 3. Hvar, 4. Korčula, 5. Pelješac, 6. Biokovo, 7. Velika Paklenica, 8. Grobnik, 9. Austria, 10. Turkey; 11. control without DNA; $\leftarrow$ polymorphic DNA bands

(Halldén et al. 1996) the optimization of the pooling DNA strategy was used in this study. It was found that the pooling DNA sample that consists of one haploid megagametophyte per individual, as well as ten individuals per population yield such RAPD amplifications in which all intensive RAPD bands of certain individuals were retained in them, that is, not any competitions between products that could lead to wrong genetic relatedness was determined (Fig. 4).

From total of 34 RAPD primers used, 21 of them yielded 190 scorable polymorphic bands (Table 2). It means that on average 9 polymorphic RAPD bands were generated per primer (Fig. 5).

Pairwise values of Jaccard's similarity coefficients ranged from 0.225 for the most distant populations (Austria and Turkey) to 0.552 for the most similar populations (Biokovo and Grobnik) (Table 3). Except that populations from Austria and Turkey showed the least mutual resemblance, they were very different from any Croatian populations. For that reason, and because of the fact that Phenetic analyses (NJ and UPGMA analysis of Jaccard and Dice distances) resulted in trees not completely identical, but compatible in their major features, only the NJ phenogram of Jaccard distances rooted with the most distant Austrian and Turkish populations, which emphasizes the relations among Croatian populations, was shown (Fig. 6). Croatian populations of black pine formed two groups. The first group comprised the island populations from Brač, Hvar and 
TABLE 2. RAPD primers that produced useful polymorphic bands among nine black pine populations.

\begin{tabular}{lcc}
\hline RAPD primers & $\begin{array}{c}\text { No. of } \\
\text { polymorphic } \\
\text { bands }\end{array}$ & $\begin{array}{c}\text { Size of } \\
\text { polymorphic } \\
\text { bands (bp) }\end{array}$ \\
\hline OPA-08 (5'-GTGACGTAGG) & 15 & $350-1650$ \\
OPA-09 (5'-GGGTAACGCC) & 6 & $700-1400$ \\
OPB-01 (5'-GTTTCGCTCC) & 12 & $450-1700$ \\
OPB-02 (5'-TGATCCCTGG) & 4 & $650-850$ \\
OPB-03 (5'CGATCCCTGG) & 7 & $400-1500$ \\
OPB-05 (5'-TGCGCCCTTC) & 15 & $500-1350$ \\
OPB-07 (5'-GGTGACGCAG) & 12 & $450-1500$ \\
OPB-08 (5'-GTCCACACGG) & 9 & $350-1300$ \\
OPB-09 (5'-TGGGGGACTC) & 2 & $750-1250$ \\
OPB-11 (5'-GTAGACCCGT) & 11 & $300-1500$ \\
OPB-12 (5'-CCTTGACGCA) & 7 & $550-1200$ \\
OPB-13 (5'-TTCCCCCGCT) & 12 & $400-1600$ \\
OPB-14 (5'-TCCGCTCTGG) & 10 & $500-1500$ \\
OPB-15 (5'-GGAGGGTGTT) & 6 & $450-1100$ \\
OPB-18 (5'-CCACAGCAGT) & 6 & $500-1550$ \\
OPB-19 (5'-ACCCCCGAAG) & 14 & $350-1600$ \\
OPB-20 (5'-GGACCCTTAC) & 10 & $450-1600$ \\
OPG-12 (5'-CAGCTCACGA) & 10 & $450-1550$ \\
OPE-08 (5'-TCACCACGGT) & 8 & $400-1300$ \\
OPE-12 (5'-TTATCGCCCC) & 7 & $450-1350$ \\
OPX-04 (5'-CCGCTACCGA) & 7 & $450-1050$ \\
\hline
\end{tabular}

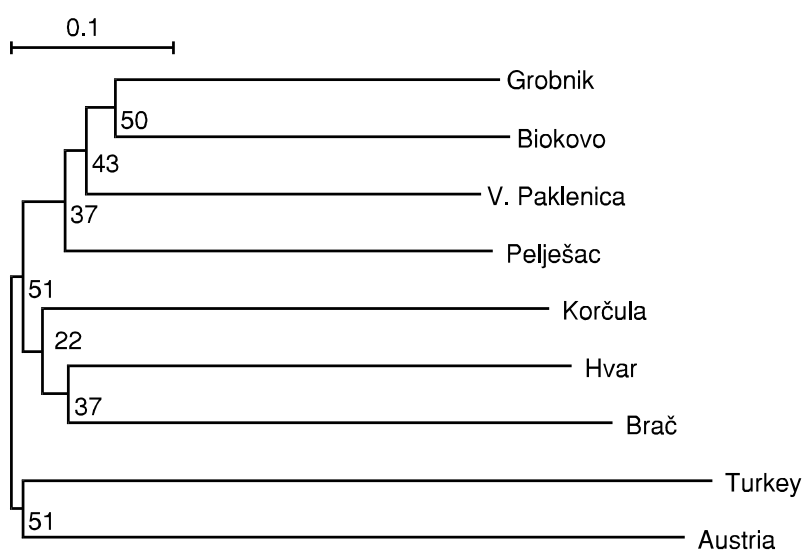

Fig. 6. Phenogram of neighbour joining analysis of Jaccard distances calculated from 190 polymorphic RAPD bands among 9 black pine populations. The tree is rooted with Austrian and Turkish population. Bootstrap values are given at a branching point denoting the \% of bootstrap trees comprising a cluster of the same composition.

Korčula, and the other consisted of populations from the Pelješac peninsula and the coastal populations from Velika Paklenica, Biokovo and Grobnik.

In the PCO analysis populations were plotted by the first three principal coordinates that accounted for nearly $50 \%$ of the total variance in the similarity matrix (Fig. 7). The first and second axes separated the most distant black pine population from Turkey while the third axis separated the black pine population from Austria. In the case of Croatian populations, it was possible, combining the first and the second axes, to distinguish the two groups, as well as the transitional population between them. The first group comprised the coastal populations (A), the second group the island populations (B), whereas the population from the Pelješac peninsula manifested characteristics of a transitional population.

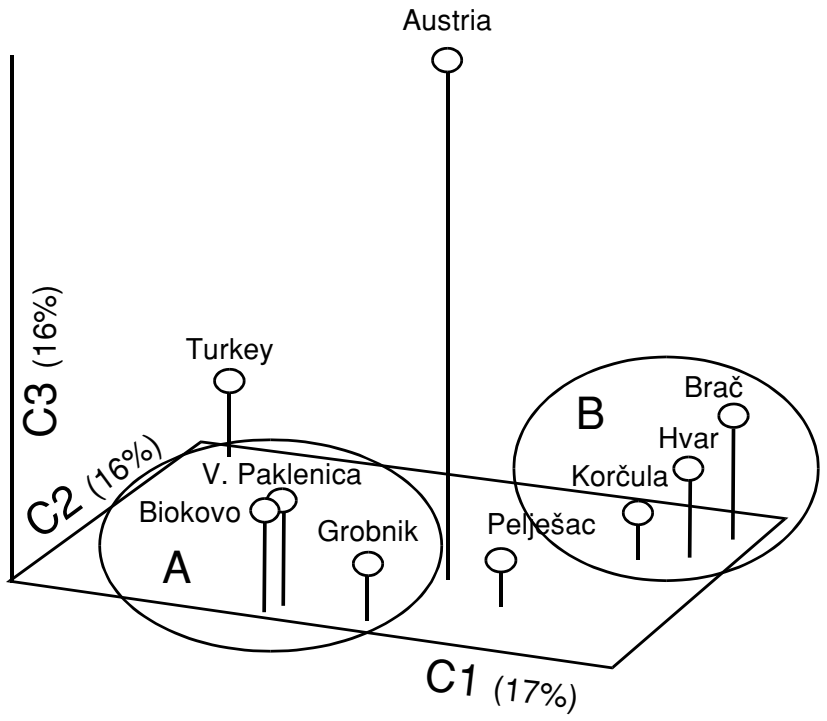

Fig. 7. Principal coordinate analysis of nine black pine populations based on RAPD data and Jaccard's similarity matrix. A - coastal populations, $\mathrm{B}$ - island populations.

\section{DISCUSSION}

Since so far no molecular method has been used for intraspecies taxonomy of the black pine, among the numerous methods suitable for the intraspecies level (SSR /Beckman and Soller 1990, Morgante et al. 1998; RAPD /Welsh and McClelland 1990; Williams et al. 1990/, SSCP /Hayashi 1992; Jordan 1998/; AFLP /Vos et al. 1995; Matthes et al. 1998/), the RAPD method was chosen for this study. Decisive in choosing this method was the fact that both simplicity and speed of data generation are incorporated in it (Williams et al. 1990), but also the facts that none of the other methods is universal and that each of them has some serious negative properties (Harris 1998).

Because one of the main problems of the traditional interspecies taxonomic research of black pine was how to supply sufficient comparative materials from the whole range (Vidaković 1991), and because it is not possible to exchange RAPD results among laboratories (Jones et al. 1997), at the beginning of this research we tried to join two things which at the first sight seem to be incompatible: the sample from the whole range of black pine (Fig. 1) and the RAPD research restricted to just one laboratory. According to the results of this study, the solution could be the use of black pine seeds as a source of tissue for DNA isolation and application of the pooling DNA strategy (Furman et al. 1997). The first advantage of black pine seeds, in comparison to the other parts of the plant body are: their high resistance to the outside conditions and their small volume. Because of that black pine seeds represent the ideal material for transportation from distant regions as well as for building the collection from the whole range. The second very important advantage of black pine seeds is that they are a source of constantly fresh tissue for DNA isolation, even when they are stored at room temperature for several years. On the other hand, the use of pooled DNAs of the populations is a kind of compromise, especially important for the research restricted to only one laboratory, because it reduces the research from the study of several thousand in- 
TABLE 3. Jaccard's similarity coefficients based on the 190 polymorphic RAPD bands among nine black pine populations.

\begin{tabular}{|c|c|c|c|c|c|c|c|c|}
\hline Population & Brač & Hvar & Korčula & Pelješac & Biokovo & Paklenica & Grobnik & Austria \\
\hline Hvar & 0.4000 & & & & & & & \\
\hline Korčula & 0.4000 & 0.3884 & & & & & & \\
\hline Pelješac & 0.4532 & 0.4126 & 0.4326 & & & & & \\
\hline Biokovo & 0.3169 & 0.4060 & 0.3955 & 0.4832 & & & & \\
\hline V. Paklenica & 0.3379 & 0.3566 & 0.4370 & 0.5302 & 0.5435 & & & \\
\hline Grobnik & 0.3566 & 0.4344 & 0.4583 & 0.4929 & 0.5520 & 0.5227 & & \\
\hline Austria & 0.3077 & 0.2977 & 0.2782 & 0.3161 & 0.3597 & 0.3803 & 0.3409 & \\
\hline Turkey & 0.2288 & 0.2719 & 0.3063 & 0.3066 & 0.3333 & 0.3359 & 0.2991 & 0.2250 \\
\hline
\end{tabular}

dividuals (Nybom and Bartish 2000) to about a hundred of populations without a complete loss of individual variability (Darvasi and Soller 1994; Furman et al. 1997).

In order to optimize the RAPD research even more, the well-known phenomena of competition between products (Williams et al. 1993), which is especially expressive in working with the pooled DNA samples (Michelmore et al. 1991; Yu and Pauls 1993), and can provide a false picture about relatedness among the researched populations (Hallden et al. 1996), was also taken into consideration. Only when a diploid embryo was cast away of the analysis, and isolation of DNA was carried out from one haploid megagametophyte per an individual, and when DNAs of 10 individuals were united in the DNA pool of populations, the competition was reduced to such extent that all the high intensity RAPD bands of certain individuals were detected in the pooled DNAs of populations (Fig. 4). Detecting of high intensity bands is especially important because only they are recommended for scoring and yielding credible genetic relatedness in the RAPD analysis (e.g. Staub et al. 1996).

The research set up in this way led to the results comparable to the previous classifications in this region, especially to those, which emphasize higher diversity of the black pine in the eastern part of its range (e.g. Vidaković 1953; Fukarek 1958; Liber et al. 2002) (Fig. 2b and 2c). Considering all the nine studied populations it can be concluded that the distribution of RAPD fragments was closely connected to the geographical position of the populations. In accordance with that, two geographically most distant populations from Austria and Turkey showed to be the most diverse populations, whereas the Croatian populations, that is geographically congruous, got settled between these two populations (Table 3, Fig. 7). If we suppose that in this analysis the clearly divided Austrian and Turkish populations represent separate subspecies (subsp. nigra and subsp. pallasiana), then according to the obtained results the Croatian populations form one, if no more, independent subspecies (Fig. 6 and 7). This conclusion points to a basic similarity of the RAPD results with the results of recently conducted morphological and anatomical studies of leaves of the same populations (Liber et al. 2002) (Table 1). In both studies it was possible to distinguish two groups of Croatian populations and a transitional population between them. The base of the groups of the Croatian populations established in both analyses represented the populations from islands of Brač, Hvar and Korčula on one hand (subsp. dalmatica), and the population from Velika Paklenica on the other hand (subsp. ilyirica) (Table 1). The differences between the two compared studies were related only to locating certain adjacent populations from Croatia into one or the other group of the Croatian populations. In such a way, in the RAPD research populations from islands of Brač, Hvar and Korčula represented an isolated group, whereas in the morphological and anatomical analyses this group was extended by populations from Pelješac and Grobnik. Contrary to that, in the RAPD study Illyric black pine comprised populations from Velika Paklenica, Grobnik and Biokovo, while in the morphological and anatomical analyses this group was restricted just to the population from Velika Paklenica. Finally, in the RAPD analysis the transitional characteristics between the determined groups of Croatian populations showed the population from the Pelješac peninsula, whereas in the morphological and anatomical analyses in this position was neighboring population from the mountain Biokovo (Table 1; Fig. 2c and 8).

Since the obtained RAPD results have showed the similarity to some of the previous classifications on this territory (Vidaković 1953; Fukarek 1958), as well as to the results of the morphological and anatomical analyses of the same populations (Liber et al. 2002), it can be concluded that the RAPD technique could be usefull for clarifying the taxonomic and classificatory unclearness within the black pine. It is assumed that the optimizations conducted in this study (the pooled DNA population, seeds as a tissue source for DNA isolation, an investigation adapted for only one laboratory etc.), will overcome the main shortages of the previous investigations because they could allow the esti-

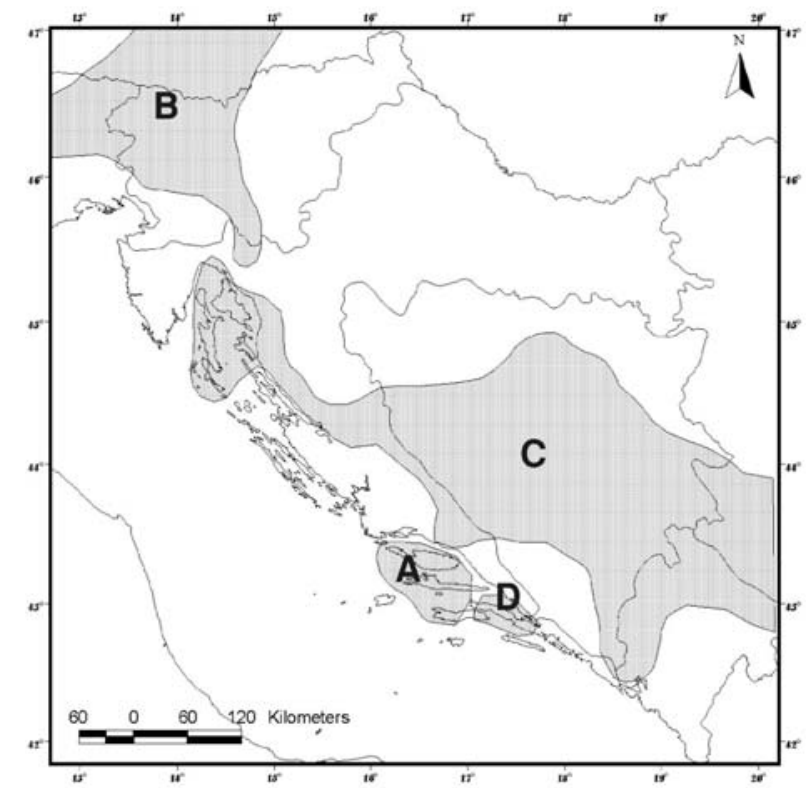

Fig. 8. Distribution of different black pine taxa in Croatia based on the RAPD results A - Pinus nigra subsp. dalmatica; B - Pinus nigra subsp. nigra, C - Pinus nigra subsp. illyrica, D - transitional population (peninsula Pelješac) 
mation of relationships on the level of the whole range of the black pine and the intraspecies classification based on molecular characteristics, probably less dependent on the environmental influences than it has been the case with the characteristics mostly used so far.

\section{ACKNOWLEDGEMENTS}

We wish to express our gratitude to Professor Dr. K. Zukrigl, who was of great help in getting samples from Austria, Professor Dr. Z. Kaya and Dr. Z. Argimak, who were of great help in getting samples from Turkey. Also many thanks to Dr. G. Lukač, Dr. J. Kamenjarin and the staff and the management of the forestry offices on the islands of Brač, Hvar, Korčula and in Makarska for the great help in the field investigations, as well as in collecting plant material from Croatia. This research was supported by the Scientific Research Council of the Republic of Croatia within the framework of project No. 119131.

\section{LITERATURE CITED}

AGUINAGALDE I., LLORENTE F., BENITO C. 1997. Relationships among five populations of European black pine ( $P i$ nus nigra Arn.) using morphometric and isozyme markers. Silvae Genet. 46 (1): 1-5.

ARBEZ M., BERNARD-DAGAN C., FILLON C.H. 1974. Variabilité intraspécifique des monoterpens de Pinus nigra Arn. bilan des premiers résultats. Ann. Sci. Forest. 114.

BARBÉRO M., LOISEL R., QUÉZEL P., RICHARDSON D.M., ROMANE F. 1998. Pines of the Mediterranean Basin. In: D.M. Richardson (ed.): Ecology and Biogeography of Pinus. Cambridge University Press, Cambridge, pp. 153-170.

BECKMAN J.S., SOLLER M. 1990. Toward a unified approach to gene mapping of eukaryotes based on sequence tagged microsatellite sites. Bio/Technology 8: 930-932.

DARVASI A., SOLLER M. 1994. Selective DNA pooling for determination of linkage between a molecular marker and quantitative trait loci. Genetics 138: 1365-1373.

DELEVOY G. 1949. A propos de la Systématique de Pinus nigra Arnold. Sta. de Rech. de Groenendaal. Travaux-Série B 12: 41 .

DEMEKE T., ADAMS R.P. 1994. The use of PCR-RAPD analysis in plant taxonomy and evolution. In: H.G. Griffin, A.M. Griffin (eds): PCR technology: current innovations. CRC Press Inc., Boca Raton, Florida, USA.

DOMAC R. 1965. Die Wälder der dalmatishen Schwarzföhre (Pinus nigra Arn. subsp. dalmatica Vis. s. 1.) in Jugoslawien. Ber. Geobot. Inst. E. T. H. Stiftung Rübel. Zurich. 36: 103-116.

DOYLE J.J., DOYLE J.L. 1990. Isolation of plant DNA from fresh tissue. Focus 12 (1): 13-15.

FELSENSTEIN J. 1985. Confidence limits on phylogenies: an approach using the bootstrap. Evolution 39: 783-791.

FUKAREK P. 1958. Prilog poznavanju crnoga bora (Pinus nigra Arn.) /Enclosure to knowledge of black pine (Pinus nigra Arn.)/. Rad. Poljopr.-Šumarsk. Fak. Univ. u Sarajevu 3: 3-92.

FURMAN B.J., GRATTAPAGLIA D., DVORAK W.S., O'MALLEY D.M. 1997. Analysis of genetic relationships of Central American and Mexican pines using RAPD markers that distinguish species. Mol. Ecol. 6: 321-331.

GAUSSEN H., HEYWOOD V.H., CHATER A.O. 1964. Pinus L.. In: T.G. Tutin, V.H. Heywood, N.A. Burges, D.M.Moore, D.H. Valentine, S.M. Walters, D.A. Webb (eds): Flora Europaea, $1^{\text {st }}$ edition, Vol. 1. Cambridge University Press, Cambridge, pp. 33-34.
GAUSSEN H., HEYWOOD V.H. 1993. Pinus L. In: T.G. Tutin, V.H. Heywood, N.A. Burges, D.M.Moore, D.H. Valentine, S.M. Walters, D.A. Webb (eds): Flora Europaea, $2^{\text {nd }}$ edition, Vol. 1. Cambridge University Press, Cambridge, pp. 42.

GEORGESCU C.C. 1937. Neue Beiträge zur Systematik der Schwarzföhre. Fed. Rep. Spec. Nov. Regni Veg. 41: 181-187.

HALLDÉN C., HANSEN M., NILSSON N.O., HJERDIN A., SALL T. 1996. Competition as a source of errors in RAPD analysis. Theor. Appl. Genet. 93: 1185-1192.

HAMRICK J.L., LINHART Y.B., MITTON J.B. 1979. Relationships between life history characteristics and electrophoretically detectable genetic variation in plants. Annual Rev. Ecol. Syst. 10: 173-200.

HARRIS S.A. 1998. RAPD in systematics - a useful methodology? In: Hollingsworth P.M., Bateman R.M., Gornall R.J. (eds): Molecular systematics and plant evolution. Taylor \& Frencis, London, pp. 211-228.

HAYASHI K. 1992. PCR-SSCP: A method for detection of mutations. Genetic Analysis, Techniques \& Applications 9: 73-79.

HILLIS D.M., MORITZ C., MABLE B.K. 1996. Molecular Systematics, $2^{\text {nd }}$ edition. Sinauer Associates Inc., Massachusetts, USA.

IVANOV P.I. 1971. Izmencivost in formovo raznobrazie na crnia bor $\mathrm{v}$ zapadnite Rodopi (Alternation of different forms of black pine in the west Rodops). Akademia na Selskostopanskite Nauki, Institut za gorata, Sofia. (in Bulgarian)

JALAS J., SUOMINEN J. 1988. Atlas florae Europaeae: distribution of vascular plants in Europe, Vol. I. Cambridge University Press, Cambridge.

JONES C. J., EDWARDS K.J., CASTIGLIONE S., WINFIELD M.O., SALA F., VAN DER WIEL C., VOSMAN B.L., MATTHES M., DALY A., BRETTSCHNEIDER R., MAESTRI, E., MARMIROLI N., AERT R.L., VOLCKAERT G., KARP A. 1997. Reproducibility testing of RAPD, AFLP and SSR markers in plants by network of Eurpean laboratories. Mol. Breed. 3: 381-390.

JORDAN W.C., FOLEY K. BRUFORD M.W. 1998. Single-stranded conformation polymorphism (SSCP) analysis In: Karp A., Isaac P.G., Ingram D.S. (eds): Molecular tools for screening biodiversity. Chapman \& Hall, London, pp. 152-156.

LIBER Z., NIKOLIĆ T., MITIĆ B. 2002. Intra- and interpopulation relationships and taxonomic status of Pinus nigra Arnold in Croatia according to morphology and anatomy of leaves. Acta Soc. Bot. Pol. 71 (2): 141-147.

LINK W., DIXENS C., SINGH M., SCHWALL M., MELCHINGER A.E. 1995. Genetic diversity in European and Mediterranean faba bean germ plasm revealed by RAPD markers. Theor. Appl. Genet. 90: 27-32.

MATTHES M.C., DALY A., EDWARDS K.J. 1998. Amplified fragment length polymorphism (AFLP). In: Karp A., Isaac P.G., Ingram D.S. (eds): Molecular tools for screening biodiversity. Chapman \& Hall, London, pp. 183-190.

MICHELMORE R.W., PARAN I., KESSELI R.V. 1991. Identification of markers linked to disease-resistance genes by bulked segregant analysis: a rapid method to detect markers in specific genomic regions by using segregating populations. Proc. Natl. Acad. Sci. U.S A. 88: 9828-9832.

MORGANTE M., PFEIFFER A., JURMAN I., PAGLIA G., OLIVERI A.M. 1998. Isolation of microsatellite markers in plants. In: In: Karp A., Isaac P.G., Ingram D.S. (eds): Molecular tools for screening biodiversity. Chapman \& Hall, London, pp. 288-296.

MORITZ C., HILLIS D.M. 1996. Molecular Systematics: Contex and Controversies. In: Hillis D.M., Moritz C., Mable B.K. (eds): Molecular Systematics, $2^{\text {nd }}$ edition, Sinauer Associates Inc., Massachusetts, USA.

MULLIS K.B., FALOONA F.A. 1987. Specific synthesis of DNA in vitro via a polymerase catalyzed chain reaction. Methods Enzymol. 155: 335-350. 
NEI M., LI W. 1979. Mathematical model for studying genetic variation in terms of restriction endonucleases. Proc. Natl. Acad. Sci. U.S A. 76: 5269-5273.

NIKOLIĆ D., TUCIĆ N. 1983. Isoenzyme variation within and among populations of European black pine (Pinus nigra Arnold). Silvae Genet. 32 (3-4): 80-89.

NYBOM H., BARTISH I.V. 2000. Effects of life history traits and sampling strategies on genetic diversity estimates obtained with RAPD markers in plants. Perspectives in Plant Ecology, Evolution and Systematics 3 (2): 93-114.

PRICE R.A., LISTON A., STRAUSS S.H. 1998. Phylogeny and Systematics of Pinus. In: Richardson D.M. (ed.): Ecology and Biogeography of Pinus. Cambridge University Press, Cambridge, pp. 49-63.

RAFFI Z.A., DODD R.S., ZAVARIN E. 1996. Genetic diversity in foliar terpenoides among natural populations of European black pine. Biochem. Syst. Ecol. 24 (4): 325-339.

RAUŠ Đ., TRINAJSTIĆ I., VUKELIĆ J., MEDVEDOVIĆ J. 1992. Biljni svijet hrvatskih šuma. In: Rauš Đ. (ed.): Šume u Hrvatskoj - Forest of Croatia, Šumarski fakultet Sveučilišta u Zagrebu, Zagreb, pp. 33-77. (in Croatian with English summary)

RONNINGER K. 1924. Über den Formenkreis von Pinus nigra Arnold. Verh. Zool. Bot. Ges. 73: 127-130.

SAITOU N., Nei M. 1987. The neighbor-joining method: a new method for reconstructing phylogenetic trees. Molec. Biol. Evol. 4: 406-425.

SAMBROOK J., FRITCH E.F., MANIATIS T. 1989. Molecular cloning: A laboratorial manuel. Cold Spring Harbor Laboratory Press, New York.

SCALTSOYIANNES A., ROHR R., PANETSOS K.P., TSAKTSIRA M. 1994. Allozyme frequency distribution in 5 European populations of black pine (Pinus nigra Arnold). Estimation of genetic variation within and among populations. 2. Contribution of isozyme analysis to the taxonomic status of the species. Silvae Genet. 43 (1): 20-30.

SCHWARZ O. 1938. Über die Systematik und Nomenklatur der europaischen Schwartzkiefern. Garten zu Berlin Dahlem XIII. 117: 226-243.

SNEATH P.H.A., SOKAL R.R. 1973. Numerical taxonomy. Freeman, San Francisco.

SOLTIS D.E., SOLTIS S.S., DOYLE J.J. 1998. Molecular systematics of plants II: DNA sequencing. Kluwer Academic Publishers, Boston, Dodrecht, London.

STAUB J., BACHER J., POETTER K. 1996. Sources of potential errors in the application of random amplified polymorphic DNAs in cucumber. Hortscience 31: 262-266.

TRINAJSTIĆ I. 1986. Šume dalmatinskog crnog bora - Pinus nigra Arnold subsp. dalmatica (Vis.) Franco - sredozemnog područja Hrvatske (Dalmatian black pine forests - Pinus nigra
Arnold subsp. dalmatica (Vis.) Franco of the Mediterranean region of Croatia). Poljopr. Šumarstvo 32 (1): 37-48. (in Croatian)

VAN DE PEER Y., DE WACHTER R. 1994. TREECON for Windows: a software package for the construction and drawing of evolutionary trees for the Microsoft Windows environment. CABIOS 10: 569-570.

VIDAKOVIĆ M. 1953. Oblici crnog bora u Jugoslaviji na temelju anatomije iglica (Types of black pines in Yugoslavia based on anatomy of needles). Disertacija-Doctoral Thesis. Poljoprivredno-šsumarski fakultet u Zagrebu. Zagreb. (in Croatian)

VIDAKOVIĆ M. 1955. Značenje anatomske graðe iglica kod svojti crnog bora u Jugoslaviji. (Importance of the anatomic structure of needles in black pine taxa in Yugoslavia). Šumarski list 7-8: 244-253. (in Croatian with English summary)

VIDAKOVIĆ M. 1957. Oblici crnoga bora u Jugoslaviji na temelju anatomije iglica. (Types of black pines in Yugoslavia based on anatomy of needles). Glasn. Šumske pokuse 13: 111-248. (in Croatian with English summary)

VIDAKOVIĆ M. 1960. Značenje češera, sjemenki i njihovih krilaca za sistematiku i za odreðivanje proviniencije crnog bora. (Importance of cone, seeds and their wings to systematics and defining the black pine provenances). Glasn. Sumske pokuse 14: 383-437. (in Croatian with English summary)

VIDAKOVIĆ M. 1991. Pinus nigra In: Vidaković M. (ed.): Conifers: Morphology and variation. Grafički Zavod Hrvatske, Zagreb, pp. 491-520.

VOS P., HOGERS R., BLEEKER M., REIJANS M., VAN DE LEE T., HORNES M, FRIJITERS A, POT J., PELEMAN J., KUIPER M., ZABEAU M. 1995. AFLP: a new technique for DNA fingerprinting. Nucleic. Acids Res. 23: 4407-4414.

WELSH J., McCLELLAND M. 1990. Fingerprinting genomes using PCR with arbitrary primers. Nucleic Acids Res. 18: 7213-7218.

WILLIAMS J.G.K., KUBELIK A.R., LIVAK K.J., RAFALSKI J.A., TINGEY S.V. 1990. DNA polymorphisms amplified by arbitrary primers are useful as genetic markers. Nucleic Acids Res. 18: 6531.

WILLIAMS J.G.K., HANAFEY M.K., RAFALSKI J.A., TINGEY S.V. 1993. Genetic analysis using random amplified polymorphic DNA markers. Methods Enzymol. 218: 704-740.

WOLFE A.D., LISTON A. 1998. Contribution of PCR-Based Methods to Plant Systematics and Evolutionary Biology. In: Soltis D.E., Soltis P.S., Doyle J.J. (eds): Molecular systematics of plants II: DNA sequencing. Kluwer Academic Publishers, Boston-Dordrecht-London, pp. 43-86.

YU K., PAULS K.P. 1993. Rapid estimation of genetic relatedness among heterogeneous populations of alfalfa by random amplification of bulked genomic DNA samples. Theor. Appl. Genet. 86: 788-794. 


\section{WYZNACZNIKI RAPD \\ A WEWNĄTRZGATUNKOWA TAKSONOMIA SOSNY CZARNEJ (PINUS NIGRA ARNOLD) - WYNIKI BADAŃ DZIEWIĘCIU POPULACJI}

\section{STRESZCZENIE}

Pomimo wieloletnich badań nad sosną czarną, wewnątrzgatunkowa taksonomia, klasyfikacja i chorologia pozostają wciąż niejasne. Ponieważ badania molekularne mogą umożliwić bardziej obiektywne studia, dlatego celem pracy było ustalenie związków między populacjami sosny czarnej przy użyciu polimorficznego DNA (RAPD). Uzyskane wyniki porównano z nowymi danymi o morfologicznych i anatomicznych właściwościach liści badanych populacji. Wyniki RAPD wyraźnie oddzieliły populacje chorwackie od austriackich (subsp. Nigra) oraz tureckich (subsp. pallasiana); równocześnie wśród chorwackich populacji stwierdzono występowanie kilku grup (subsp. illyrica, subsp. dalmatica oraz populacje pośrednie. Uzyskane w niniejszych badaniach podsumowanie umożliwi ocenę związków na poziomie całego zasięgu sosny czarnej oraz klasyfikację jednostek opartą na cechach molekularnych.

SŁOWA KLUCZOWE: sosna czarna, rozmieszczenie, taksonomia wewnątrzgatunkowa, systematyka, RAPD. 